\title{
Türkiye'de Düzey-2 Bölgeleri Arasında Kişi Başı Gelir Yakınsama Kulüpleri Var Mıdır?
}

\section{Şekip YAZGAN ${ }^{1}$ \\ Reşat CEYLAN ${ }^{2}$}

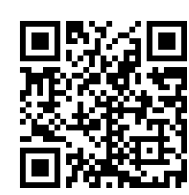

\begin{tabular}{ccc}
\hline Geliș Tarihi/ Received & Kabul Tarihi/ Accepted & Yayın Tarihi/ Published \\
15.06.2021 & 01.10 .2021 & 15.10 .2021 \\
\hline Citation/Atıf: Yazgan Ş. ve Ceylan R., (2021), Türkiye'de Düzey-2 Bölgeleri Arasında Kişi Başı Gelir \\
Yakınsama Kulüpleri Var Mıdır?, Atatürk Üniversitesi İktisadi ve İdari Bilimler Dergisi, 35(4): Sayfa: 1497- \\
1519, https://doi.org/10.16951/atauniiibd.952620
\end{tabular}

Öz: Türkiye'de 26 düzey-2 bölgesi için kişi başı gelir yakınsaması hipotezinin 2004-2018 döneminde, Phillips ve Sul (2007) tarafından geliştirilen kulüp yakınsaması tekniği ile incelendiği bu çalışmanın iki amacı bulunmaktadır. Bu amaçlardan birincisi, yakınsama kulüplerini belirlemek ve ikincisi de yakınsama kulüplerinin oluşumunun arkasında yatan yapısal çerçeveyi ortaya koymaktır. Elde edilen bulgulara göre ele alınan dönemde 8 yakınsama kulübü ve bir tane de ıraksama kulübü bulunmaktadır. Bu sonuçlar, yakınsama kulüplerinin oluşumunda yakın komşuluk ilişkilerinin ve öne çıkan ekonomik sektörlerin belirleyici olduğunu ortaya koyması bakımından önemlidir.

Anahtar Kelimeler: Kulüp Yakınsama Hipotezi, Bölgesel Eşitsizlik, Bölgesel Kalkınma.

\section{Are There Per Capita Income Convergence Clubs Among NUTS-2 Regions in Turkey?}

Abstract: This study, in which the per capita income convergence hypothesis for 26 level-2 regions in Turkey was examined in the 2004-2018 period with the club convergence technique developed by Phillips and Sul (2007), has two purposes. The first of these aims is to identify the convergence clubs and the second is to reveal the structural framework behind the formation of convergence clubs. According to the findings, there are 8 convergence clubs and one divergence club in the period under consideration These results are important in terms of revealing that close neighborhood relations and prominent economic sectors are determinants in the formation of convergence clubs.

Keywords: Club Convergence Hypothesis, Regional inequality, Regional Development

Jel Codes:C23, R11, R12

${ }^{1}$ Dr. Öğr. Üyesi, A $\breve{g r}$ İbrahim Çeçen Üniversitesi, İktisadi ve İdari Bilimler Fakültesi, İktisat Bölümü,syazgan@agri.edu.tr,https://orcid.org/0000-0003-1006-668X

${ }^{2}$ Prof. Dr. Pamukkale Üniversitesi, İktisadi ve İdari Bilimler Fakültesi, İktisat Bölümü, rceylan@pau.edu.tr,https://orcid.org/0000-0003-3727-6644 
Türkiye'de Düzey-2 Bölgeleri Arasında Kişi Başı Gelir Yakınsama Kulüpleri Var Mıdır?

\section{EXTENDED SUMMARY}

Aim: Club convergence hypothesis, which is a fundamental criticism against the neoclassical convergence model, argues that countries with similar conditions and positions at the beginning will reach similar stable balances in the long run and form convergence clubs, and inequality between the countries that make up these clubs will decrease. In this context, there are two main purposes of this study, in which the per capita income convergence hypothesis for 26 NUTS-2 regions in Turkey is handled with the club convergence technique developed by Phillips and Sul (2007) in the 2004-2018 period. The first of these main objectives is to identify the convergence clubs and the second is to reveal the structural framework behind the formation of convergence clubs.

Methods: In the study, club convergence technique developed by Phillips and Sul (2007) is used to examine the per capita income convergence hypothesis for the period of 2004-2018 for 26 NUTS-2 regions in Turkey. Phillips and Sul (2007) technique, also known as the log t convergence test, is based on a unique coefficient that allows heterogeneity between the units in the sample and includes a time-transition effect. This method loosens many assumptions such as the common factor among the units in the panel and the variables being trend stationary and having a stochastic non-stationary structure. In this respect, Phillips and Sul (2007) technique focuses on tourism, environment, foreign trade, energy consumption, happiness, etc. used in many different fields.

Findings: According to the results of Phillips and Sul (2007) convergence analysis, it is seen that there are 8 convergence clubs and 1 divergence club, although a general convergence result could not be obtained for 26 NUTS-2 regions during the study period.

Results: In the study, the absence of a general convergence for all NUTS2 regions seems to be the first important result obtained in the analysis. This finding is important because it reveals that there is no general convergence pattern at the regional level in Turkey during the 2004-2018 period, and that the initial conditions and structural parameters of all NUTS-2 regions are not identical. The second important result obtained in the analysis carried out within the framework of Phillips and Sul (2007) methodology is the determination that there are 8 convergence clubs between regions that are in convergence behavior. It is considered that partly the neighborhood structure of the regions and partly the prominent sectors in the regions are determinant in the formation of the mentioned convergence clubs. It is evaluated that the club convergence pattern between the regions obtained in the study may cause the regional inequalities to become permanent in Turkey. 


\section{Giriş}

Bölgesel düzeyde gözlemlenen gelişmişlik farklılıklarının, ülke ekonomilerinde oluşan temel yapısal sorunlardan biri olarak değerlendirildiği ve özellikle gelişme sürecinde olan ve kaynakların adil dağılmadığı ülkelerde ekonomik büyüme önünde önemli bir engel teşkil ettiği, yapılan çalışmalarla ortaya konulmaktadır (Karahasan ve Bilgel, 2018:341; Türkcan ve Çelik, 2020:5).

Bu kapsamda, 1950'li yıllardan itibaren ekonomik büyüme ve bölgesel gelișme literatürleri arasında sıkı bir ilişkinin ortaya çıtı̆̆ 1 ve 1990'lı yılların başından itibaren de Solow (1956) tarafindan geliştirilmiş olan Neo-klasik büyüme modelinin temel çıkarımı olan yakınsama hipotezinin, ekonometrik tekniklerdeki gelişmeler ile yaygın bir uygulama alanı haline geldiği söylenebilmektedir. Yakınsama hipotezine ilişkin teorik açıklamaların Barro ve Sala-i Martin (1992)'in çalışmasıyla birlikte ortaya konması, yakınsama hipotezinin bölgeler arası gelişmişlik farklılıklarının analizinde de kullanılabileceğini göstermiştir. Her ne kadar yakınsama hipotezinin ilk ampirik uygulaması Baumol (1986)'un çalışması olsa da asıl büyük sıçramanın 1990'lı yıllarda gerçekleştiğini belirtmek yerinde olacaktır. Yakınsama hipotezinin test edilmesinde yatay-kesit regresyon analizlerinin popüler hale geldiği 1990'l1 yıllarda, zamanla birim kök testleri ve panel veri analizleri de öne çıkmıştır. Ayrıca, yakınsama hipotezinin dağılım yaklaşımları ile analizi Quah $(1993,1996)$ çalışmaları ile başlamıştır. İzleyen süreçte Neoklasik yakınsama modeline karşı temel bir eleştiri getiren Quah (1993), temelde ortalamadaki bir yakınsamanın yanıltıcı olabileceğini ve eşitsizliklerin genelde ifade ettiği yapı ile yerel düzeyindeki yansımalarının özdeş olmayabileceğini belirterek bölgeler arasında gerçekleşecek ortalama bir yakınsamadan ziyade bölgelerin hangi gelir gruplarına doğru hareket ettiğini anlamanın daha önemli olduğunu ortaya koymaktadır. Quah (1993) tarafindan yapılan bu tespitler "Galton Yanlışı" olarak literatürdeki yerini almış ve yakınsama hipotezinin teorik alt yapısının yeniden inşa edilmesi yönünde girişimlerin de başlangıcı olmuştur. Bölgelerin kümelenmesi ve kulüp yakınsama hipotezi olarak tanımlanan bu süreç ile 1990'lı yıllarda bölgesel eşitsizliklerin açıklanamayan yapısı ortaya konulmaktadır (Karahasan ve Bilgel,2018:342-344). Formülasyonu Durlauf ve Johnson (1995) ve Galor (1996) tarafından yapılan kulüp yakınsama hipotezine gösterilen ilginin ise Phillips ve Sul (2007) tarafından geliştirilen kümeleme yöntemiyle arttığı görülmektedir (Aksoy vd., 2019: 1186). Söz konusu yöntem, analize dâhil olan ülkeleri veri matrisindeki benzerliklere göre gruplandıran ve her bir grup içerisinde yakınsama olup olmadığını test eden ve kendi aralarında yakınsama örüntüsüne sahip olan ülkeleri ayrıştıran yeni bir kulüp yakınsama analizi önermektedir (Apergis ve Payne, 2017:367).

Çalışmada, Türkiye'de İstatistiki Bölge Birimleri Sınıflandırması (IBBSS) kapsamında Düzey-2 bölgeleri boyutuyla bölgesel eşitsizliklerin kulüp 
yakınsama hipotezi çerçevesinde Phillips ve Sul (2007, 2009) tarafindan geliştirilen kümeleme yöntemi kullanılarak incelenmesi amaçlanmaktadır. Bu kapsamla çalışmanın girişi izleyen birinci bölümünde, kulüp yakınsama hipotezi teorik ve ampirik düzeyde ortaya konulmakta ve çalışmanın literatürdeki konumu belirtilmektedir. İkinci ve üçüncü bölümde sırasıyla analizde kullanılan veri ve metodoloji açıklanmakta ve analizlerde elde edilen sonuçlar sunulmaktadır. Çalışma, elde edilen bulguların özetlendiği ve değerlendirildiği sonuç bölümüyle tamamlanmaktadır.

\section{Teorik ve Ampirik Literatür}

İktisadi büyüme literatürünün tartıştığı en önemli konulardan birisinin Solow (1956) modelinin temel çıkarımı olan yakınsama hipotezi olduğu ifade edilmektedir. Yakınsama hipotezi kökeni 18. Yüzyıla kadar uzanan, İngiltere ile İskoçya arasındaki birleşme sürecinin kime daha çok yarar sağlayacağının tartışıldığ 1 bir meseledir (Elmslie, 1996). Teorik olarak yakınsama hipotezi, Solow Modelinde ölçeğe göre sabit getirili Cobb-Douglas tipi üretim fonksiyonunda sermaye faktörü için azalan getirinin bir sonucu olarak elde edilmektedir. $\mathrm{Bu}$ hipoteze göre, zengin ülkelerde göreli olarak bol olan sermayenin marjinal ürünü düşük, fakir ülkelerde ise göreli olarak kıt olan sermayenin marjinal ürünü yüksektir. Dolayısıyla bu durum, fakir ülkelerin zengin ülkelere göre daha yüksek bir büyüme hızına sahip olmaları sonucunu yaratmaktadır. Fakir ülkelerin, zengin ülkelere göre daha yüksek bir büyüme hızına sahip olmaları onlara doğru bir yakınsama sürecinin oluşacağını ima etmektedir. Neo-klasik büyüme teorisinin temelini oluşturan ve azalan verimler temel varsayımına dayanan Solow (1956) modeli, ülkeler ya da bir ülkenin bölgeleri arasında görülen gelir farklılıklarının geçici olduğunu ve uzun dönemde bütün ülkelerde/bölgelerde kişi başı gelir seviyelerinin eşitleneceğini başka bir ifadeyle ülke/bölgelerin birbirlerine yakınsayacaklarını öngörmektedir (Dinler, 2014:39-40).

Yakınsama hipotezi, ölçeğe göre sabit getiri ve azalan verimler varsayımı altında birbirleriyle adeta yarışan ve test edilebilir üç hipotez ortaya koymaktadır (Galor, 1996:1056):

i. Mutlak Yakınsama Hipotezi: Ülkelerin kişi başına geliri, uzun vadede başlangıç koşullarından bağımsız olarak birbirlerine yakınsamaktadır.

ii. Koşullu Yakınsama Hipotezi: Tüketici tercihleri, teknolojileri, nüfus artış hızları, hükümet politikaları vb. gibi yapısal özellikleri benzer olan ülkelerin kişi başına geliri uzun vadede başlangıç koşullarından bağımsız olarak birbirlerine yakınsamaktadır.

iii. Kulüp Yakınsama Hipotezi: Yapısal özellikleri benzer olan ülkelerin kişi başına gelirleri, başlangıç koşullarının da aynı olması şartıyla uzun vadede birbirine yakınsamaktadır. 
Neo-klasik büyüme teorisi, dengenin tekliği ilkesine dayanmaktadır. Bu kapsamda söz konusu bu üç yakınsama hipotezine bakıldığında, mutlak yakınsama hipotezinde, tüm ekonomilerin yaklaştığı tek bir denge bulunmaktayken, koşullu yakınsama hipotezinde denge farklılaşmakta ve her bir ekonomi kendi özel dengesine sahip olmaktadır. Kulüp yakınsama hipotezinde ise çoklu denge üreten modeller bulunmakta ve ekonomilerin bu farklı dengelerden hangisine ulaşacağı başlangıç pozisyonlarına bağlı olarak belirlenmektedir (Ceylan,2010:56-57). Kulüp yakınsama hipotezine göre, başlangıçta özdeş/benzer koşul ve konumlara sahip olan ülkelerin, uzun dönemde özdeş durağan dengelere ulaşarak yakınsama kulüplerini oluşturacağ 1 ve kulübü oluşturan ülkeler arasında eşitsizliğin azalacağı ileri sürülmektedir. Bu yönüyle kulüp yakınsamasının çoklu durağan-durum dengeleri ve sabit/artan verimler dikkate alan içsel büyüme teorisine dayandığg ifade edilebilmektedir (Azariadis ve Drazen, 1990; Romer, 1990; Grosman ve Helpman,1991).

İktisadi büyüme literatüründe kulüp yakınsama sürecine ulaşan genel model üzerinde uzlaş1lamaması ve standart ekonometrik modellerle sürecin analiz edilememesi gibi problemlerin ortaya çıkmasını takip eden süreçte Durlauf ve Johnson (1995) ve Galor (1996) tarafindan kulüp yakınsama hipotezinin formülasyonunun gerçekleştirilmesi ve Phillips ve Sul $(2007,2009)$ tarafından geliştirilen yöntemle birlikte kulüp yakınsama hipotezini inceleyen çalışmaların sayısının arttı̆̆ görülmektedir.

Bu kapsamda ampirik literatürde gelişmiş (Örneğin, Bartkowska and Riedl (2012); Monfort, vd. (2013) Apergis vd. (2010) vb.) ve gelişmekte olan ülkeler (Örneğin, Ghosh vd. (2013) Tian vd. (2016); Martin and Vazquez (2015) vb.) üzerine yapılmış birçok çalışma bulunmaktadır. Türkiye'de ise iller/bölgeler düzeyinde yakınsama hipotezini mutlak ve koşullu yakınsama hipotezi boyutlarıyla inceleyen çok sayıda çalışmanın bulunduğu (Örneğin, Filiztekin (1998), Kalyoncu (2001), Karaca (2004), Erlat (2005), Karaalp ve Erdal (2005), Yamanoğlu (2008), Zeren ve Yılancı (2011) vb.) ancak konuyu kulüp yakınsama hipotezi boyutuyla inceleyen çalışmaların ise oldukça sınırlı sayıda olduğu görülmektedir.

Söz konusu çalışmalardan Karagöl vd. (2019), Phillips ve Sul (2007) tarafından geliştirilen kulüp yakınsama analizini kullanarak 2004-2017 yılları arasındaki dönemde 81 il/Düzey 3 bölgesinde kişi başına gelirin yakınsamasını test etmektedir. Çalışmada Phillips ve Sul (2007) analizi prosedürü çerçevesinde ilk aşamada panelin tamamında yakınsama bulunmadığ 1 tespit edilmekte, ikinci aşamada ise alt gruplar ve kulüpler içerisinde yakınsama davranışı incelenerek 7 yakınsama kulübü olduğu ifade edilmektedir. İkinci aşamada ise çalışmada, Phillips ve Sul (2009) tarafından geliştirilen yöntem kullanılarak orijinal kulüplerin birleşip yeni kulüpler oluşturup oluşturmadıklarını incelemeye imkân veren analiz kullanılmakta ve böylece kulüp sayısı 5'e inmektedir. Çalışmada, 
kulüp yakınsama sonuçlarının verimlilik düzeylerindeki eşitsizlikler, coğrafi faktörler ve yapısal farklılıklardan etkilenebileceği belirtilmektedir.

Phillips ve Sul (2007) tarafından geliştirilen kulüp yakınsama analizini kullanarak Türkiye'de 81 il/Düzey 3 bölgesinde kişi başına gelirin yakınsamasını test eden diğer bir çalışma olan Aksoy vd. (2019) ise inceleme dönemi olarak 1987-2001 ve 2004-2017 olmak üzere iki alt dönemi belirlemektedir. Çalışmada elde edilen tahmin sonuçları, mutlak ve koşullu yakınsama boyutlarıyla Türkiye'de genel bir gelir yakınsaması bulunmadığını ancak ve her iki dönemde de sırasıyla 5 ve 6 yakınsama kulübü olduğunu göstermektedir. Aksoy vd. (2019) çalışmasında elde edilen sonuçlar, daha zengin kulüplerin Türkiye'nin Batı'sında, daha yoksul olanların ise Türkiye'nin Doğu ve Güneydoğu'sunda yer aldığını göstermektedir. Çalışmada belirlenen yakınsama kulüplerinin belirlenmesi için sıralı logit modelinin kullanıldığ ikinci aşamasında ise, kişi başı başlangıç geliri, beşerî sermaye ve toplam kredilerin kulüplerin ortaya çıkmasındaki en önemli değişkenler olduğu ifade edilmektedir.

Son olarak Karahasan (2020) ise çalışmasında, 1975-2017 döneminde Türkiye'de 81 ilde/Düzey 3 bölgesinde, bölgelerin komşu olmasının kulüp yakınsaması üzerindeki etkilerini incelemektedir. İnceleme döneminde Türkiye'deki 81 il/Düzey 3 bölgesinde ortalamaya yakınsama olmadığı ve dolayısıyla kulüp yakınsama hipotezinin geçerli olduğunu ifade eden çalışmada elde edilen sonuçlar inceleme döneminde Türkiye'de kulüp yakınsama sürecinin komşu bölgelerin gelir seviyelerinden etkilendiği sonucunu ortaya koymaktadır. Karahasan (2020) çalışmasında ayrıca zengin bölgelerle komşu olan bölgelerin daha yüksek gelirli bölgelerin sınıfına yönelme şansı bulunduğunu, yoksul bölgelerde bulunan bölgelerin ise aynı gelir grubunda kalabileceğini ya da daha düşük gelir gruplarının seviyesine düşebileceğini ve dolayısıyla Türkiye'de tarihsel olarak gözlemlenen bölgesel eşitsizliklerin kalıcı hale geldiği ifade edilmektedir.

Bu kapsamda çalışmada, literatürde Türkiye üzerine yapılan çalışmalardan farklı olarak 2004-2018 yılları arasındaki dönemde kulüp yakınsama hipotezinin İBBS kapsamında 26 düzey-2 bölgesi için Phillips ve Sul (2007) tarafından geliştirilen kümeleme yöntemi kullanılarak incelenmektedir. Ülkeler bölgesel kalkınma politikaları olarak tanımlanan ve çeşitli politika araçlarını kullanarak, bölgelerin refah seviyelerini yükseltmek, sosyal ve ekonomik kalkınmanın tüm bölgelere yaygınlaşmasını sağlamak ve dolayısıyla bölgelerarası farklılıkları ortadan kaldırmayı amaçlayan politikalar uygulamaktadır (Kaya, 2020: 103). Söz konusu bölgesel kalkınma politikası araçlarından birisi ise bölgesel kalkınma ajansları olarak karşımıza çıkmaktadır. Bölgesel kalkınma ajansları ile kamunun finansman sağladığı bölgesel ekonomik gelişmeyi özendirmek tasarlanmakta ve bu yönüyle söz konusu ajanslar bölgesel kalkınmanın gerçekleşmesinde önemli roller almaktadır İlk olarak Büyük Buhran'ın ardından 1933 yılında Amerika Birleşik Devletleri'nde uygulanmaya başlayan ve takip eden yıllarda Avrupa 
ülkelerinde hayata geçirilen bölgesel kalkınma ajanslarının Türkiye'de de 2006 yılından itibaren kurulmaya başlandığı görülmektedir. Türkiye'de İBBS kapsamında 26 düzey- 2 bölgesinde 26 tane kalkınma ajansı bulunmaktadır ${ }^{3}$.IBBS kapsamında düzey-2 bölgelerinin oluşturulasında coğrafi yakınlık faktörü kriter olarak alınmaktadır. Söz konusu bu kriterin, bölgeler arasındaki sınır komşuluğuna dayalı etkileşimlerin analiz edilmesi yönüyle avantaj sağladığı, ancak yalnızca sınır komşusu oldukları için farklı sosyo-iktisadi gelişmişlik düzeyine sahip illerin aynı bölgeler içerisinde değerlendirilmesi yönüyle de dezavantajlı durumu beraberinde getirdiği ifade edilmektedir Buna karşın, bölgesel politikaların belirlenmesi ve uygulamasında İBBS kapsamında düzey-2 seviyesi belirlenmektedir (Türkcan ve Çelik,2020:19-22). Bu yönleriyle çalışmanın, Düzey-2 bölgelerinde kulüp yakınsama hipotezine yönelik kanıtlar sunmasının yanı sıra bölgesel kalkınma ajansları ve kulüp yakınsama hipotezi arasındaki ilişkiyi de ortaya koyarak literatürde Türkiye üzerine yapılan çalışmalardan ayrıştı̆̆ değerlendirilmektedir.

\section{Metodoloji}

Bu çalışmada, log t yakınsama testi olarak da adlandırılan Phillips ve Sul (2007) tarafından geliştirilen panel yakınsama kulübü ve göreli geçiş fonksiyonları yöntemi kullanılmaktadır. Phillips ve Sul (2007) tekniği, örneklemde bulunan birimler arasında heterojenliğe izin veren ve zaman-geçişli etkiyi içinde barındıran kendine özgü bir katsayıya dayanmaktadır. Bu yöntem, panelde bulunan birimler arası ortak faktör ve ele alınan değişkenlerin trend durağan olması ve stokastik durağan olmayan bir yapıya sahip olması gibi birçok varsayımı gevşetmektedir. Bu yönüyle Phillips ve Sul (2007) tekniği turizm, çevre, dış ticaret, enerji tüketimi, mutluluk vb. gibi birçok farklı alanda kullanılmaktadır (Kourtzidis vd. (2018), Panopoulou and Pantelidis (2009), Apergis ve Cooray (2016), Ivanovski vd. (2018), Apergis and Georgellis (2013)).

Verilerin Türkiye İstatistik Kurumu (TÜIK) veri tabanından alındığı ve Türkiye' deki 26 düzey-2 bölgesi için kişi başı gelir yakınsaması analizinin 20042018 dönemi için yapıldığ 1 bu çalışmada, $y_{i t}$, her bir bölge için kişi başı gelir düzeyi olup $i=1,2, \ldots, N$ ve $t=1,2, \ldots, T$ olmak üzere sirasıly bölge ve yıl sayısını göstermektedir. Phillips ve Sul (2007) tekniği takip edilerek modeldeki bağımlı değişken $y_{i t}$, sistematik $\left(g_{i t}\right)$ ve geçici $\left(d_{i t}\right)$ olmak üzere iki bileşene ayrilmaktadır:

$$
y_{i t}=g_{i t}+d_{i t}
$$

Denklem (1), panelde bulunan her bir birim için, sistematik ve geçici bileşenleri ifade edecek şekilde aşağıdaki gibi yeniden yazılmaktadır.:

\footnotetext{
${ }^{3}$ Düzey-2 bölgeleri ve söz konusu bölgelerde bulunan bölgesel kalkınma ajansları çalışma ekinde sunulmaktadir.
} 
Türkiye'de Düzey-2 Bölgeleri Arasında Kişi Başı Gelir Yakınsama Kulüpleri Var Mıdır?

$$
y_{i t}=\left(\frac{g_{i t}+d_{i t}}{\mu_{t}}\right) \mu_{t}=\delta_{i t} \mu_{t}, \quad \forall i, t
$$

Görüldüğü gibi denklem (2)'de iki bileşen bulunmaktadır. Bunlardan birincisi, hem deterministik ve hem de stokastik bileşenlere sahip olabilen ve grup için bir durağan-durum trend fonksiyonunu temsil eden $\mu_{t}$, ikincisi ise, hem zaman ve hem de birime özel etkileri yansıtan ayrıca, ortak çarpan $\mu_{t}$ ile $y_{i t}$ arasındaki uzaklığı ölçen birime özgü bir unsur olan $\delta_{t}$ olarak ifade edilmektedir. Ayrıca, $\delta_{t}$ katsayısı, panelde bulunan her bir birim için ortak etki çarpanı $\mu_{t}$ 'nin payının bir ölçüsüdür. Phillips ve Sul (2007) yönteminde yakınsama dinamik bir süreç olarak varsayılmaktadır. Dolayısıyla, $\delta_{i t}$ katsayısı geçiş patikalarını göstermekte ve kişi başı gelir yakınsaması da $\delta_{i t}$ katsayısının geçici göreli davranış yolu ile test edilebilmektedir. Phillips ve Sul (2007) yönteminde, $\delta_{i t}$ katsayısı için yakınsama hipotezini test etmeye uygun, yarı-parametrik bir süreç ele almaktadır. Spesifik olarak ortak bileşen $\mu_{t}$, panel ortalamasına bölünerek elimine edilebilmektedir:

$$
h_{i t}=\frac{y_{i t}}{\frac{1}{N} \sum_{i=1}^{N} y_{i t}}=\frac{\delta_{i t}}{\frac{1}{N} \sum_{i=1}^{N} \delta_{i t}}
$$

Burada, $h_{i t}$, panel ortalamasına göre, göreli geçiş yolunun bir ölçüsüdür. Göreli geçiş yolu parametresi kısa dönemde ülkeler arasında farklı olabilmekte, ancak her bir ülke için göreli geçiş yolu parametresi bire yaklaşırken uzun dönem yakınsama çıkarımını vermektedir. Uzun dönemde yakınsama çıkarımının yapılabilmesi için, göreli geçiş yolu parametresinin yatay-kesit varyansının sıfıra yaklaşması gerekmektedir. Bu durumda, $\delta_{i t}$ 'nin yakınsama kulübü algoritması için aşağıdaki varsayımın yapılması gerekmektedir:

$$
\delta_{i t}=\delta_{i}+\sigma_{i t} \gamma_{i t}
$$

Bu denklemde $\sigma_{i t}=\frac{\sigma_{i}}{L(t) t^{a}}, \sigma_{i}>0$ ve $\gamma_{i t}$ zaman boyunca zayıf bağımlı olabilmekte, fakat her bir $i$ için i.i.d. $(0,1) L(t)$ fonksiyonu $t$ 'de artan ve $t$ sonsuza yöneldiğinde rraksak olduğu belirtilmektedir. $\delta_{i t}$ için bu özel form altında, tüm $i$ 'ler için yakınsamanın boş hipotezi, $H_{0}: \delta_{i}=\delta, a \geq 0$ alternatif hipotez ise; $H_{A}: \delta_{i} \neq \delta$ veya $a<0$ olarak ifade edilmektedir. Özel olarak ise, burada verilen hipotez testleri $a$ 'nın işaretine indirgenebilmektedir. Panelde yer alan birimlerin özel bir grubu için yakınsamanın boş hipotezi reddedildiğinde, bu çıkarım ilgili birimlerin panelde yer alan başka kümelere yakınsamayacağ anlamına gelmemektedir. Bu yüzden, panelin bütünü için yakınsamanın varlığının reddedilmesi, panelde çoklu yakınsama kulüplerinin varlığına işaret etmektedir.

Phillips ve Sul (2007, aşağıdaki denklem kullanılarak sözü edilen yakınsama olgusunun test edilebileceğini ileri sürmektedir: 


$$
\log \left(\frac{H_{1}}{H_{t}}\right)-2 \log L(t)=\hat{c}+\hat{b} \log t+\hat{u}_{t}
$$

Burada; $H_{t}=\frac{1}{N} \sum_{i=1}^{N}\left(h_{i t}-1\right)^{2}$ olup, göreli geçiş katsayılarının yatay kesit uzaklı̆̆ının karesi olarak ifade edilmektedir. Phillips ve Sul (2007), (5) denkleminin tahmini için $t=[r t],[r t]+1, \ldots, T$ ve $r[0.2,0.3]$ olmasını önermektedir. 5 numaralı denklemde, $\hat{b}=2 \hat{a}$ olduğuna dikkat edilirse, boş hipotez aynı zamanda $\hat{b}>0$ 'n $\hat{b}<0$ 'a karşı olacak şekilde de düzenlenebilmektedir. Bu tek yönlü test için eğer, $t_{\hat{b}}<-1,65$ ise yakınsama hipotezinin geçerliliğini gösteren boş hipotez reddedilmektedir. Bu test, panelde yer alan farklı yakınsama kulüplerini ortaya çıkarmak için de uygulanabilmektedir. Phillips ve Sul (2007), paneldeki yakınsama kulüplerini belirlemek için aşağıdaki kümelenme algoritmasının takip edilebileceğini belirtmektedir:

i. Bölgeler, zaman serilerinin son değerlerine göre sıralanmaktadır;

ii. En üst sıradaki bölgeden başlayarak, sıralanan listedeki en yakın bölgeler eklenir. Her oluşum için (5) denklemi tahmin edilir. Ardından, kesme noktası kriteri kullanılarak çekirdek grup seçilmektedir.

iii. Geri kalan bölgeler, birer birer çekirdek gruba eklenerek veri seti elenir ve denklem (5) her bir oluşum için yeniden tahmin edilir. Ardından eklenen bölgenin çekirdek grupta kalıp kalmayacağına karar vermek için işaret kriterine bakılmaktadır.

iv. Geri kalan bölgeler için, (ii) ve (iii) aşamaları, yakınsama kulübü oluşmayıncaya kadar adım adım tekrarlanır. Her bir kulüp kendi yakınsama patikasına uygun hareket eder. Eğer en son grup, bir yakınsama örüntüsüne sahip değilse, bu grubun üyelerinin rraksama kulübünü oluşturduğu çıkarımı yapılabilir. Son olarak, $-1.65<t_{\hat{b}}<0$ aralığında bulunan kulüpler, zayıf iraksak olarak nitelendirilmektedir.

Bu kapsamda çalışmanın sonraki bölümünde yukarıda açıklanan Phillips ve Sul (2007) metodolojisi, Türkiye'de 26 düzey-2 bölgenin inceleme dönemi olan 2004-2018 yılları arasında kişi başı gelir verilerine uygulanmakta ve elde edilen sonuçlar değerlendirilmektedir.

\section{Temel Bulgular}

Phillips ve Sul (2007) tarafından önerilen yöntemin Türkiye'de 26 düzey2 bölgenin 2004-2018 yılları arasında dolar cinsinden kişi baş1 gelir verilerine uygulanması sonucunda elde edilen sonuçlar aşağıda Tablo.1'de gösterilmektedir. Çalışmada kullanılan veri seti Türkiye İstatistik Kurumu (TÜIK)'ten elde edilmektedir. Tabloda da görüldügü üzere Phillips ve Sul (2007) yöntemi prosedürü doğrultusunda ilk aşamada 26 düzey-2 bölgenin tamamında yakınsama davranışı içerisinde bulunmadığı sonucuna, panelin tamamı için hesaplanan $\mathrm{t}$ istatistik değerinin kritik değer olan $-1,65$ 'ten küçük olması 
neticesinde ulaşılmaktadır. Tabloda ifade edilen $\beta$ katsayısı ise yakınsama hızını göstermekte ve durağan durum dengesine her bir dönemde ne oranda yaklaşıldığını ifade etmektedir. Phillips ve Sul (2007) metodolojisinin ikinci aşamasında ise alt gruplar ve kulüplerin belirlenmesine geçilmektedir. $\mathrm{Bu}$ kapsamda çalışmada Phillips ve Sul (2007) metodolojisi kullanılarak 26 düzey-2 bölgesinin toplam 8 alt kulüp oluşturduğu sonucuna ulaşılmaktadır. Başka bir ifadeyle yakınsama analiz sonuçlarına göre 26 düzey-2 bölge için genel bir yakınsama sonucu elde edilememekle birlikte kendi içerisinde yakınsayan 8 yakınsama kulübü oluşmaktadır. Bunun yanında analiz neticesinde, TR32 ve TR61 düzey-2 bölgelerinin, 8 yakınsama kulübüne dahil olmadığı ve aralarında yakınsama bulunmadığı ve bu iki bölgenin bir ıraksama kulübü oluşturduğu tespit edilmektedir. Söz konusu 8 yakınsama kulübü ve bu kulüplerin içinde bulunan düzey-2 bölgeleri ${ }^{4}$ Tablo.1 ve Şekil.1' $\mathrm{de}^{5}$ sunulmaktadır.

Tablo 1: Phillips ve Sul (2007) Analizi Sonuçları

\begin{tabular}{|c|c|c|c|}
\hline Kategori & Böl & $\boldsymbol{\beta}$ & $t$ \\
\hline Panelin Tümü & 26 Düzey-2 Bölge & -0.668 & -7.889 \\
\hline Kulüp 1 & TR42, TR81, TR90, TRA1, TRB2, TRC3 & 0.578 & 1.781 \\
\hline Kulüp 2 & TR33, TRB1 & 0.302 & 1.763 \\
\hline Kulüp 3 & TR52, TR62, TR63, TRA2 & 0.391 & 1.061 \\
\hline Kulüp 4 & TR71, TR72, TR83 & -0.387 & -1.215 \\
\hline Kulüp 5 & TR41, TRC1 & -0.433 & -0.766 \\
\hline Kulüp 6 & TR10, TR22 & 1.755 & 10.819 \\
\hline Kulüp 7 & TR21, TR31 & 1.509 & 2.955 \\
\hline Kulüp 8 & TR51, TR82, TRC2 & 2.125 & 1.528 \\
\hline \multicolumn{4}{|c|}{$\begin{array}{l}\text { Phillips ve Sul (2007) analiz sonuçlarının sunulduğu Tablo.1 } \\
\text { değerlendirildiğinde, tüm düzey-2 bölgeleri için genel bir yakınsamanı } \\
\text { bulunmamasının analizde elde edilen ilk önemli sonuç olduğu görülmektedir. Bu } \\
\text { bulgu, Türkiye'de } 2004-2018 \text { döneminde bölgesel düzeyde genel bir yakınsama } \\
\text { örüntüsünün bulunmadığını, düzey-2 bölgelerinin bütününün başlangı̧ } \\
\text { koşullarının ve yapısal parametrelerinin özdeş olmadığını ortaya koymas1 } \\
\text { bakımından önemlidir. Phillips ve Sul (2007) metodolojisi çerçevesinde analizde } \\
\text { elde edilen ikinci önemli sonuç ise bölgeler arasında birbirlerine yakınsama } \\
\text { davranış1 içerisinde bulunan } 8 \text { yakınsama kulübünün bulunduğunun tespit } \\
\text { edilmesi olmaktadır. Bu kapsamda, söz konusu yakınsama kulüplerinin ortaya } \\
\text { çıkmasının arkasında iki temel faktörün etkili olabileceği değerlendirilmektedir. }\end{array}$} \\
\hline
\end{tabular}

${ }^{4}$ Tüm düzey-2 bölgeleri ve söz konusu bölgeler kapsamındaki iller çalışma ekinde sunulmaktadır. ${ }^{5}$ Analiz sonuçlarıyla elde edilen 8 adet yakınsama ve 1 adet ıraksama kulübünün ayrı ayrı grafiksel gösterimleri çalışma ekinde sunulmaktadır. 
Söz konusu faktörlerden birincisi, analiz sonucunda belirlenen yakınsama kulüplerinin aralarında kısmen/tamamen coğrafi komşuluk ilişkisinin bulunması olarak ifade edilebilmektedir. Coğrafi komşuluk, ortak iklim ve bitki örtüsü, benzer sosyal ve ekonomik yap1 gibi yapısal karakteristikleri belirleyen özellikleri içinde barındırabilir. Yakınsama kulüpleri içerisinde, kulüp 1'de, TR42, TR81 ve TR90, TRA1, TRB2, TRC3; kulüp 3'te TR52, TR62, TR63; kulüp 4'te TR71, TR72, TR83 ve kulüp 8'de TR51ve TR82 düzey-2 bölgelerinin birbirlerine coğrafi olarak komşu bölgeler olduğu görülmektedir. Bu açıdan bakıldığında 8 tane yakınsama kulübü içerisinde yer alan 24 düzey-2 bölgesinin 14 tanesi birbirine komşu bölgelerden, 10 tanesi ise birbirine komşu olmayan, ancak öne çıan ortak ekonomik sektörlerin bulunduğu bölgelerden oluşmaktadır. Phillips ve Sul (2007) kulüp yakınsama analizinden elde edilen bu sonuçlar Karahasan (2020) tarafindan ifade edilen kulüp yakınsama sürecinin komşu bölgelerin gelir seviyelerinden etkilendiği sonucuyla uyumlu bir sonuç olarak karşımıza çıkmaktadır.

İnceleme döneminde Türkiye'de Düzey-2 bölgelerinde yakınsama kulüplerinin oluşumunda etkisi olduğu değerlendiren ikinci faktörün ise, bölgelerde öne çıkan sektörlerin olduğu ifade edilebilmektedir. Türkiye'de İBBS2 bölgelerinin güçlü ve zayıf yönlerine dayalı olarak rekabetçi üstünlüğe sahip oldukları endüstri kollarının Yerelleşme Katsayıları metodolojisiyle elde edildiği Türkcan ve Çelik (2020) çalışmasının sonuçlarına göre, Kulüp 2 bünyesinde bulunan TR33 ve TRB1 bölgelerinde Madencilik ve Taşocaklığı, Kulüp 5'de bulunan TR41 ve TRC1 bölgelerinde İmalat, Kulüp 7 içerisinde yer alan TR21 ve TR31 bölgelerinde ise Tarım, Ormancılık ve Balıkçlık endüstri dallarının öne çıkan endüstriler konumunda bulunmaktadır. Bu aşamada sırasıyla TR10 bölge koduyla ifade edilen İstanbul'un başta bilişim ve finans sektörleri olmak üzere birçok endüstri kolunda diğer bölgelerden üstünlüğünün bulunduğunu ve diğer bölgelerden belirgin bir şekilde ayrıştı̆̆ını belirtmek gerekmektedir (Türkcan ve Çelik, 2020:137-168). Türkcan ve Çelik (2020) çalışmalarında, Türkiye'de 26 İBBS-2 bölgesi kapsamında, 17 ana endüstri ve 87 alt endüstri koluna ait, çalışan sayıs1, firma sayıs1 ve maddi mallara yönelik yatırım tutarları gibi makro büyüklüklerin 2009-2015 yılları arasını kapsayan dönemdeki aritmetik ortalamalarına dayalı olarak Yerelleşme Katsayıları hesaplanmaktadır. Yerelleşme katsayıs1, herhangi bir endüstri kolunun herhangi bir bölgede ulusal ekonomiyle mukayese edildiğinde ne derecede yoğunluk sergilediğini göstermektedir (Türkcan ve Çelik, 2020: 140-141). 


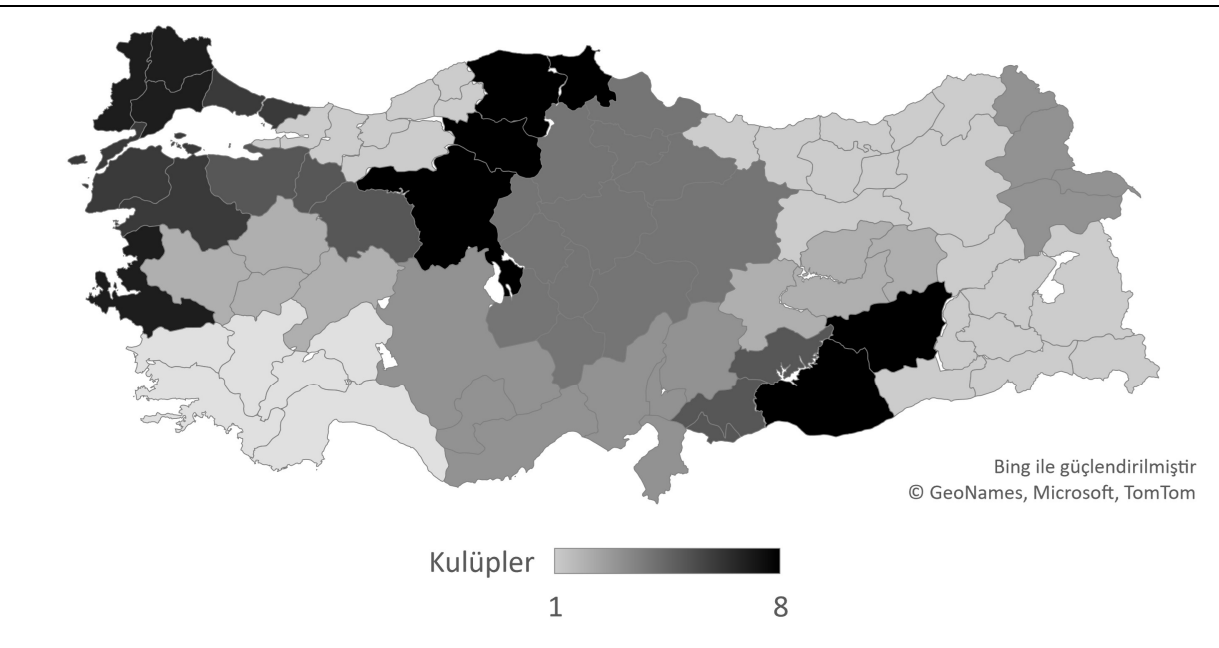

Şekil 1: Phillips ve Sul (2007) Analizi Sonuçlart

Iraksama kulübü içerisinde yer alan, TR32 ve TR61 düzey-2 bölgeleri ise, hem bölgeler arasında komşuluk ilişkisi bulunması hem de iki bölgede de turizm sektörüyle ilişkili Konaklama ve Yiyecek Hizmeti Faaliyetleri sektörünün ön planda olmasına rağmen yukarıda ifade edilen kulüp yakınsama örüntüsünden farklılaştığı ifade edilebilmektedir.

Çalışmada elde edilen sonuçlar, 26 düzey-2 bölgenin tamamında yakınsama davranışı bulunmadığını ve dolayısıyla bir bölgesel kalkınma aracı olarak söz konusu bölgelerde bulunan kalkınma ajanslarının sosyal ve ekonomik kalkınmanın tüm bölgelere yaygınlaşmasını sağlamak ve dolayısıyla bölgelerarası farklılıkları ortadan kaldırma konusunda yeterince başarılı olamadığını göstermektedir. Analiz neticesinde elde edilen diğer bir önemli sonuç ise, 26 düzey-2 bölgesinin toplam 8 adet yakınsama kulübü oluşturması olmaktadır. Yakınsama kulüplerinin oluşmasında kısmen bölgelerin komşuluk yapısı ve kısmen de bölgelerde öne çıkan sektörlerin belirleyici olduğu değerlendirilmektedir.

\section{Sonuç ve Değerlendirme}

Ülke ekonomilerinde gözlemlenen temel yapısal sorunlardan biri olarak değerlendirilen bölgesel eşitsizlikler ülkelerin ekonomik performansları önünde önemli bir engel teşkil etmektedir. Bu çerçevede bölgesel eşitsizlikleri gidermeyi amaçlayan politikaların belirlenmesi ülke içerisindeki bölgesel eşitsizliklerin dinamiklerinin belirlenmesiyle mümkün olmaktadır.

Bu kapsamda çalışmada, Neo-klasik yakınsama modeline karşı temel bir eleştiri geliştiren kulüp yakınsama hipotezinin, Türkiye'de inceleme dönemi olan 2004-2018 y1lları arasını kapsayan dönemde 26 düzey-2 bölgesi için Phillips ve Sul (2007) tarafindan geliştirilen yöntem kullanılarak incelenmesi 
amaçlanmaktadır. Kulüp yakınsama hipotezi, başlangıçta özdeş/benzer koşul ve konumlara sahip olan ülkelerin, uzun dönemde özdeş durağan dengelere ulaşarak yakınsama kulüplerini oluşturacağ eşitsizliğin azalacağını ileri sürmektedir. Çalışmada elde edilen yakınsama analiz sonuçlarına göre 26 düzey-2 bölge için genel bir yakınsama sonucu elde edilemediği ve kendi içerisinde yakınsayan 8 yakınsama kulübü bulunduğu görülmektedir. Analiz neticesinde belirlenen yakınsama kulüpleri içerisinde yer alan 24 düzey-2 bölgesinin 14 tanesinin birbirine komşu bölgelerden, 10 tanesi ise birbirine komşu olmayan bölgelerden oluştuğu görülmektedir. Literatürde Türkiye üzerine yapılan sınırlı sayıda bulunan çalışmalarda da elde edilen bu sonucun yanında, bölgelerde öne çıkan sektörlerinin benzeşmesinin de yakınsama kulüplerinin oluşumunda belirleyici bir faktör olabileceği değerlendirilmektedir. İstanbul'un başta bilişim ve finans sektörleri olmak üzere birçok endüstri kolunda diğer 25 adet bölgeden belirgin bir şekilde ayrıştığ1 görülmekle birlikte, kulüp 2, Kulüp 5 ve kulüp 7 içerisinde yer alan düzey-2 bölgelerinde sırasıyla, Madencilik ve Taşocaklığı, İmalat ve Tarım, Ormancıllık ve Balıkçılık endüstri dallarının öne çıkan endüstriler konumunda bulunduğu görülmektedir. $\mathrm{Bu}$ kapsamda söz konusu yakınsama kulüplerinin ortaya çıkmasında kısmen bölgelerin arasındaki komşuluk ilişkisi ve kısmen de bölgelerde öne çıkan sektörlerin belirleyici olduğu değerlendirilmektedir. Ulaşılan bu sonuçlara karşın, rraksama kulübü içerisinde yer alan bölgelerin ise hem bölgeler arasında komşuluk ilişkisi bulunması hem de iki bölgede de turizm sektörüyle ilişkili Konaklama ve Yiyecek Hizmeti Faaliyetleri sektörünün ön planda olmasına rağmen yukarıda ifade edilen kulüp yakınsama örüntüsünden farklılaştığı ifade edilebilmektedir.

Çalışmada elde edilen tüm bu sonuçlar, bölgesel kalkınma, bölgesel dengesizliklerin giderilmesi ve bölgesel kalkınma ajansları ilişkisi açısından da önem arz etmektedir. Bölgesel kalkınma politika aracı olarak kullanılan bölgesel kalkınma ajansları ile sosyal ve ekonomik kalkınmanın tüm bölgelere yaygınlaşmasını sağlayarak bölgelerarası farklılıkları ortadan kaldırmak amaçlamaktadır. Türkiye'de İBBS kapsamında 26 düzey-2 bölgesinde 26 tane kalkınma ajansı bulunmaktadır. Bu kapsamda çalışmada elde edilen söz konusu bölgeler arasında genel bir yakınma sürecinin bulunmaması sonucu, inceleme döneminde Türkiye'de kalkınma ajanslarının bölgesel eşitsizlikleri giderme konusunda yeterince başarılı olamadığını göstermektedir. Bunun yanında, yakınsama kulüplerinin ortaya çıkmasında kısmen bölgelerin arasındaki komşuluk ilişkisinin belirleyici olduğu sonucu ve zengin bölgelerle komşu olan bölgelerin daha yüksek gelirli bölgelerin sınıfina yönelme şansı bulunduğu, yoksul bölgelerde bulunan bölgelerin ise aynı gelir grubunda kalabileceğini ya da daha düşük gelir gruplarının seviyesine düşebileceği olgusu hatırlanacak olursa, çalışmada elde edilen Türkiye'de bölgeler arasındaki kulüp yakınsama 
örüntüsünün, bölgesel eşitsizlerin kalıcı hale gelmesine sebep olabileceği değerlendirilmektedir.

\section{Kaynaklar}

Apergis, N., Panopoulou, E., \& Tsoumas, C. (2010). Old Wine in a New Bottle: Growth Convergence Dynamics in the EU. Atlantic Economic Journal, 38(2), 169-181.

Aksoy, T., Taştan, H., \& Kama, Ö. (2019). Revisiting Income Convergence in Turkey: Are there Convergence Clubs?. Growth and Change, 50,11851217.

Apergis, N., \& Cooray, A. (2016). Old Wine in A New Bottle: Trade Openness and FDI Flows-Are the Emerging Economies Converging?. Contemporary Economic Policy, 34(2), 336-351.

Apergis, N., \& Georgellis, Y. (2013). Does Happiness Converge?. Journal of Happiness Studies, 16 (1), 67-76.

Apergis, N., \& Payne, J. E. (2017). Per Capita Carbon Dioxide Emissions Across U.S. States by Sector and Fossil Fuel Source: Evidence from Club Convergence Tests. Energy Economics, 63: 365-372.

Azariadis, C., \& Drazen, A. (1990). Threshold Externalities in Economic Development. Quarterly Journal of Economics, 105(2),501-526.

Barro, R., \& Sala-i Martin, X. (1992). Convergence. Journal of Political Economy, 100(2), 223-251.

Bartkowska, M., \& Riedl, A. (2012). Regional Convergence Clubs in Europe: Identification and Conditioning Factors. Economic Modelling, 29(1), 2231.

Ceylan, R. (2010). Yakınsama Hipotezi: Teorik Tartışmalar. Sosyoekonomi, 1, 47-60.

Dinler, Z. (2014), Bölgesel İktisat, Bursa: Ekin Basın Yayın Dağıtım.

Durlauf, S.N., \& Johnson, P.A. (1995). Contoversy on the Convergence and Divergence of Growth Behavior. Journal of Applied Econometrics, 10(4),365-384.

Elmslie, B.T. (1995). Retrospectives The Convergence Debate Between David Hume and Josiah Tucker. Journal of Economic Perspectives, 9(4), 207216.

Erlat, H. (2005), Türkiye'de Bölgesel Yakınsama Sorununa Zaman Dizisi Yaklaşımı, Ed. Haluk Erlat içinde, Bölgesel Gelişme Stratejileri ve Akdeniz Ekonomisi (s. 251-276) Ankara: Türkiye Ekonomi Kurumu.

Galor, O. (1996). Convergence? Inferences from Theoretical Models. The Economic Journal, 106 (437), 1056-1069.

Grossman, G. M., \& Helpman, E. (1991). Innovation and Growth in the Global Economy. Cambridge MA: MIT Press. 
Ghosh, M., Ghoshray, A., \& Malki, I. (2013). Regional Divergence and Club Convergence in India. Economic Modelling, 30,733-742.

Ivanovski, K., Awaworyi Churchill, S., \& Smyth, R. (2018). A Club Convergence Analysis of Per Capita Energy Consumption Across Australian Regions and Sectors. Energy Economics, 76, 519-531.

Karaca, O. (2004), Türkiye'de Bölgeler Arası Gelir Farklılıkları: Yakınsama Var M1?. Türkiye Ekonomi Kurumu Tartışma Metni, 7, 1-16.

Karaalp, H.S., \& Erdal, F. (2009), Türkiye'de İller ve Bölgeler Arasında Gelir Farklı1ıkları: Sigma Yakınsama Analizi”, International Davraz Congress, Social and Economic Issues Shaping The World's Future: New Global Dialog, Süleyman Demirel Üniversitesi, Isparta/Türkiye.

Karagöl, E.T., Görüş, Ş., \& Özgür, Ö. (2019), "Club Convergence in Turkey: Evidence from Provincial Income Data", Uluslararası Yönetim, Ekonomi ve Politika Kongresi, İstanbul/Türkiye.

Karahasan, B.C., \& Bilgel, F. (2018), Türkiye'de Bölgesel Eşitsizlikler: Yakınsama, Dağılım ve Mekân. Der. N. Engin, E. Aslanoğlu, O. Erdoğan, B.C. Karahasan, K. Tata içinde, Türkiye Ekonomisinde Kalkınma ve Dönüşüm (s. 341-380), Ankara: İmge Kitabevi.

Karahasan, B.C. (2020), Can Neighbor Regions Shape Club Convergence? Spatial Markov Chain Analysis for Turkey. Letters in Spatial and Resource Sciences, 13,117-131.

Kaya, A.A. (2020). Bölgesel Kalkınma Politikalarında Devletin Rolü. Der. M. Tiryakioğlu içinde, Devletle Kalkınma Fikret Şenses'e Armă̆an (s. 103145), İstanbul: İletişim.

Kourtzidis, S. A., Tzeremes, P., Tzeremes, N. G., \& Heryan, T. (2018). Integration of Tourism Markets in Australia: An International Visitor Arrival' Convergence Assessment. Tourism Economics, 24(7), 901-907.

Martin, V., \& Vazquez, G. (2015). Club Convergence in Latin America. The BE Journal of Macroeconomics, 15(2), 791-820.

Monfort, M., Cuestas, J. C., \& Ordonez, J. (2013). Real Convergence in Europe: A Cluster Analysis. Economic Modelling, 33,689-694.

Quah, D. (1993). Empirical Cross-section Dynamics in Economic Growth. European Economic Review, 37(2-3),426-434.

Phillips, P. C. B., \& Sul, D. (2007). Transition Modeling and Econometric Convergence Tests. Econometrica, 75(6),1771-1855.

Phillips, P.C.B., \& Sul, D. (2009). Economic Transition and Growth. Journal of Applied Econometrics, 24 (7),1153-1185.

Panopoulou, E., \& Pantelidis, T. (2009). Club Convergence in Carbon Dioxide Emissions. Environmental and Resource Economics, 44(1), 47-70. 
Türkiye'de Düzey-2 Bölgeleri Arasında Kişi Başı Gelir Yakınsama Kulüpleri Var Mıdır?

Romer, P. M. (1990). Endogenous Technological Change. Journal of Political Economy, 98(5), 71-102.

Solow, R.M. (1956) A Contribution to the Theory of Economic Growth. The Quarterly Journal of Economics, 70(1), 65-94.

Tian, X., Zhang, X., Zhou, Y., \& Yu, X. (2016). Regional Income Inequality in China Revisited: A Perspective from Club Convergence. Economic Modelling, 56, 50-58.

Türkcan. B., \& Çelik, N. (2020), Türkiye'de Bölgesel İktisat Teori-UygulamaPolitika. Ankara: Orion Kitabevi.

Yamanoğlu, K. B. (2008). Türkiye'de Sosyo Ekonomik Faktörlerin İller Arası Yakınsama Üzerine Etkileri. İstatistikçiler Dergisi, 1, 33- 49.

Zeren, F., \& Yılanc1, V. (2011). Türkiye'de Bölgeler Arası Gelir Yakınsaması: Rassal Katsay1l Panel Veri Analizi Uygulamas1. Business and Economics Research Journal, 2(1),143- 151.

Ekler:

\begin{tabular}{cl} 
& \multicolumn{1}{c}{ Ek 1: IBBBS - Düzey-2 Bölgeleri } \\
\hline Bölge Kodu & \multicolumn{1}{c}{} \\
\hline TRA1 & Erzurum, Erzincan, Bayburt \\
TRA2 & Ağrı, Kars, Iğdı,, Ardahan \\
TRB1 & Malatya, Elâzığ, Bingöl, Tunceli \\
TRB2 & Van, Muş, Bitlis, Hakkâri \\
TRC1 & Gaziantep, Adıyaman, Kilis \\
TRC2 & Şanlurura, Diyarbakır \\
TRC3 & Mardin, Batman, Şırnak, Siirt \\
TR10 & İstanbul \\
TR21 & Tekirdağ, Edirne, Kırklareli \\
TR22 & Balıkesir, Çanakkale \\
TR31 & İzmir \\
TR32 & Aydın, Denizli, Muğla \\
TR33 & Manisa, Afyonkarahisar, Kütahya, Uşak \\
TR41 & Bursa, Eskişehir, Bilecik \\
TR42 & Kocaeli, Sakarya, Düzce, Bolu, Yalova \\
TR51 & Ankara \\
TR52 & Konya, Karaman \\
TR61 & Antalya, Isparta, Burdur \\
TR62 & Adana, Mersin \\
TR63 & Hatay, Kahramanmaraș, Osmaniye \\
TR71 & Kırıkkale, Aksaray, Niğde, Nevşehir, Kırşehir \\
TR72 & Kayseri, Sivas, Yozgat \\
TR81 & Zonguldak, Karabük, Bartın \\
TR82 & Kastamonu, Çankırı, Sinop \\
TR83 & Samsun, Tokat, Çorum, Amasya \\
TR90 & Trabzon, Ordu, Giresun, Rize, Artvin, Gümüşhane \\
\hline &
\end{tabular}


Ek 2: IBBS - Düzey-2 Bölgeleri Düzey 2 Bölgeleri ve Kalkınma Ajanslart

\begin{tabular}{cl}
\hline Bölge Kodu & Bölgesel Kalkınma Ajansları \\
\hline TRA1 & Kuzeydoğu Anadolu Kalkınma Ajansı \\
TRA2 & Serhat Kalkınma Ajansı \\
TRB1 & Fırat Kalkınma Ajansı \\
TRB2 & Doğu Anadolu Kalkınma Ajansı \\
TRC1 & İpekyolu Kalkınma Ajansı \\
TRC2 & Karacadağ Kalkınma Ajansı \\
TRC3 & Dicle Kalkınma Ajansı \\
TR10 & İstanbul Kalkınma Ajansı \\
TR21 & Trakya Kalkınma Ajansı \\
TR22 & Güney Marmara Kalkınma Ajansı \\
TR31 & İzmir Kalkınma Ajansı \\
TR32 & Güney Ege Kalkınma Ajansı \\
TR33 & Zafer Kalkınma Ajansı \\
TR41 & Bursa Eskişehir Bilecik Kalkınma Ajansı \\
TR42 & Doğu Marmara Kalkınma Ajansı \\
TR51 & Ankara Kalkınma Ajansı \\
TR52 & Mevlana Kalkınma Ajansı \\
TR61 & Batı Karadeniz Kalkınma Ajansı \\
TR62 & Çukurova Kalkınma Ajansı \\
TR63 & Doğu Akdeniz Kalkınma Ajansı \\
TR71 & Ahiler Kalkınma Ajansı \\
TR72 & Orta Anadolu Kalkınma Ajansı \\
TR81 & Batı Karadeniz Kalkınma Ajansı \\
TR82 & Kuzey Anadolu Kalkınma Ajansı \\
TR83 & Orta Karadeniz Kalkınma Ajansı \\
TR90 & Doğu Karadeniz Kalkınma Ajansı \\
\hline
\end{tabular}

Ek 3: Phillips ve Sul (2007) Analizi Sonuçları: Yakınsama Kulüpleri Ek 3.1: Kulüp 1 Bölgeleri

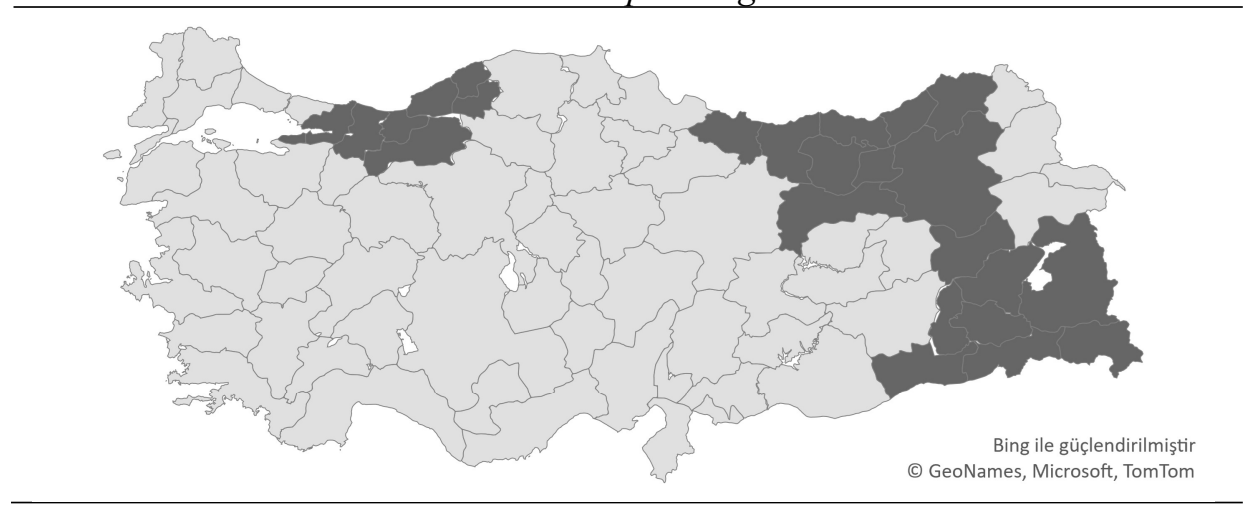


Türkiye'de Düzey-2 Bölgeleri Arasında Kişi Başı Gelir Yakınsama Kulüpleri Var Mıdır?

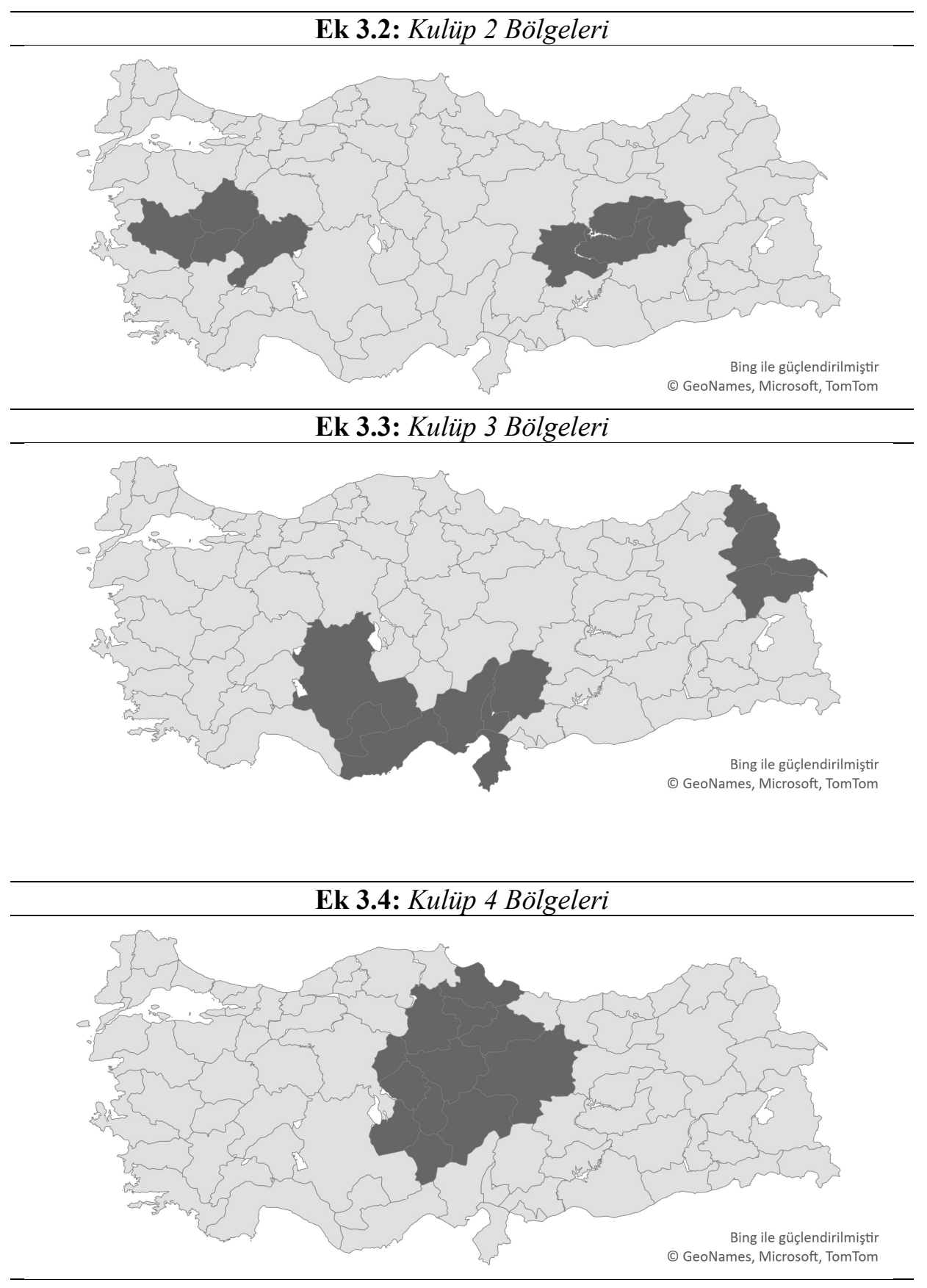




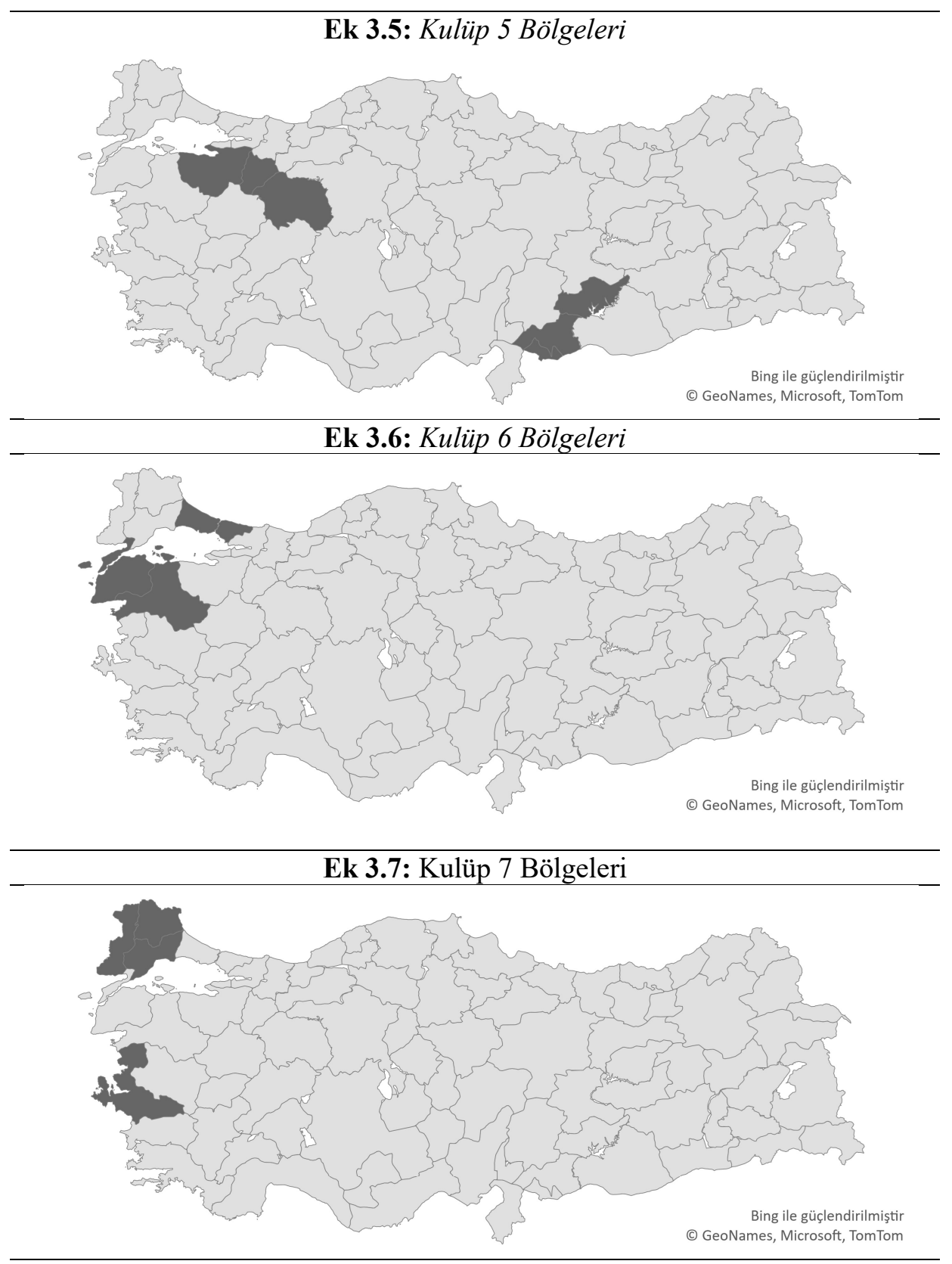


Türkiye'de Düzey-2 Bölgeleri Arasında Kişi Başı Gelir Yakınsama Kulüpleri Var Mıdır?

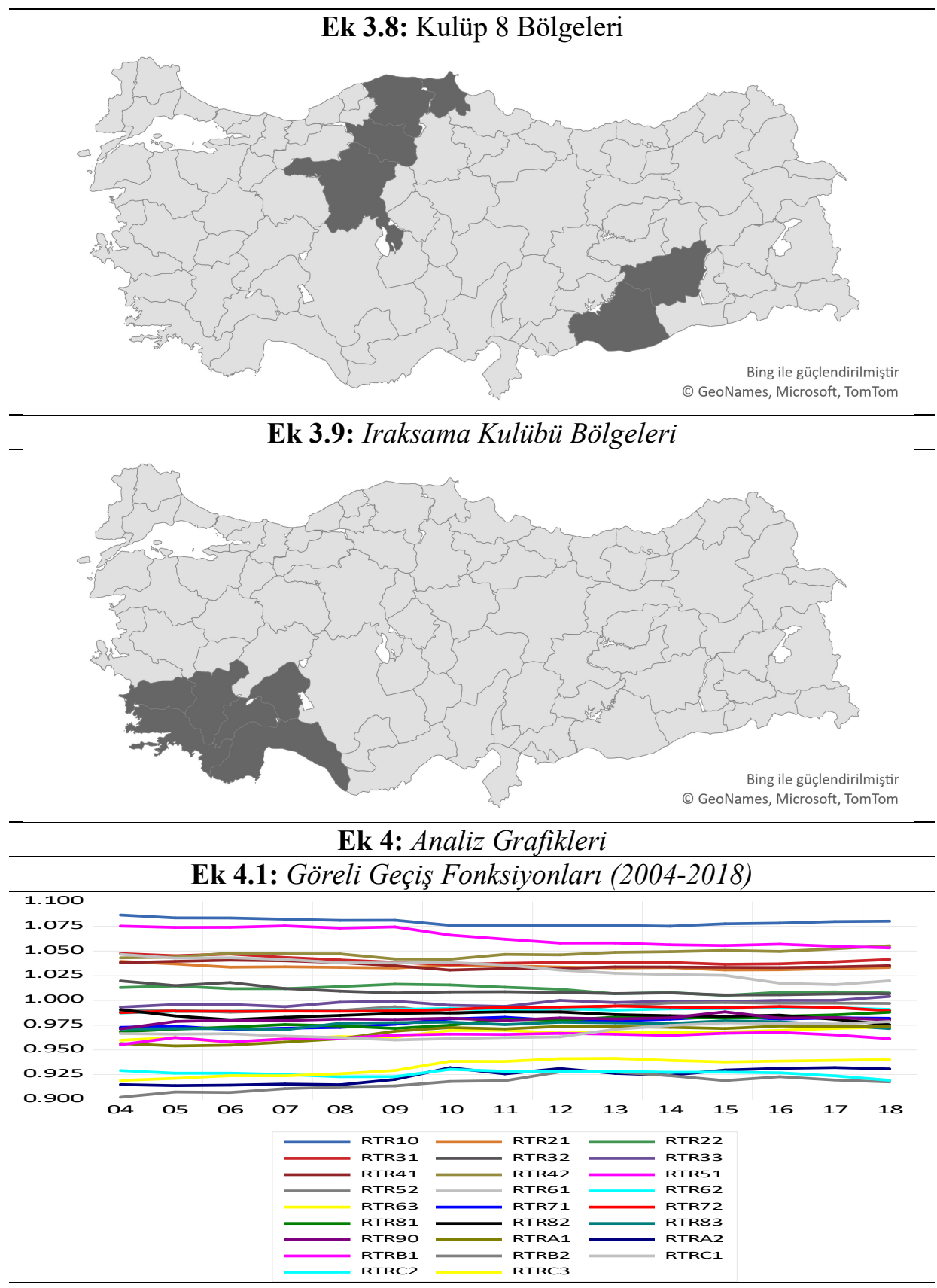


Ek 4.2: 1. Yakınsama Kulübü

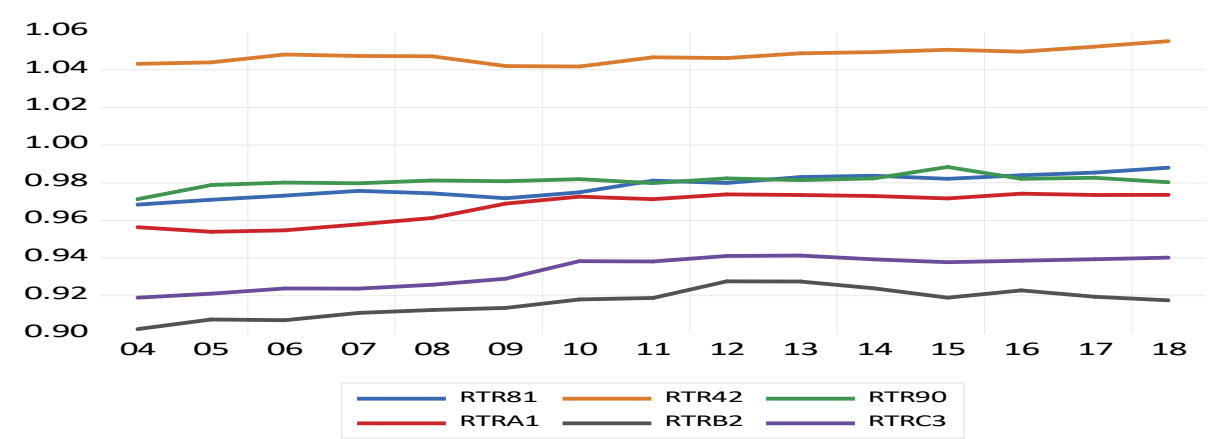

Ek 4.3: 2. Yakınsama Kulübü
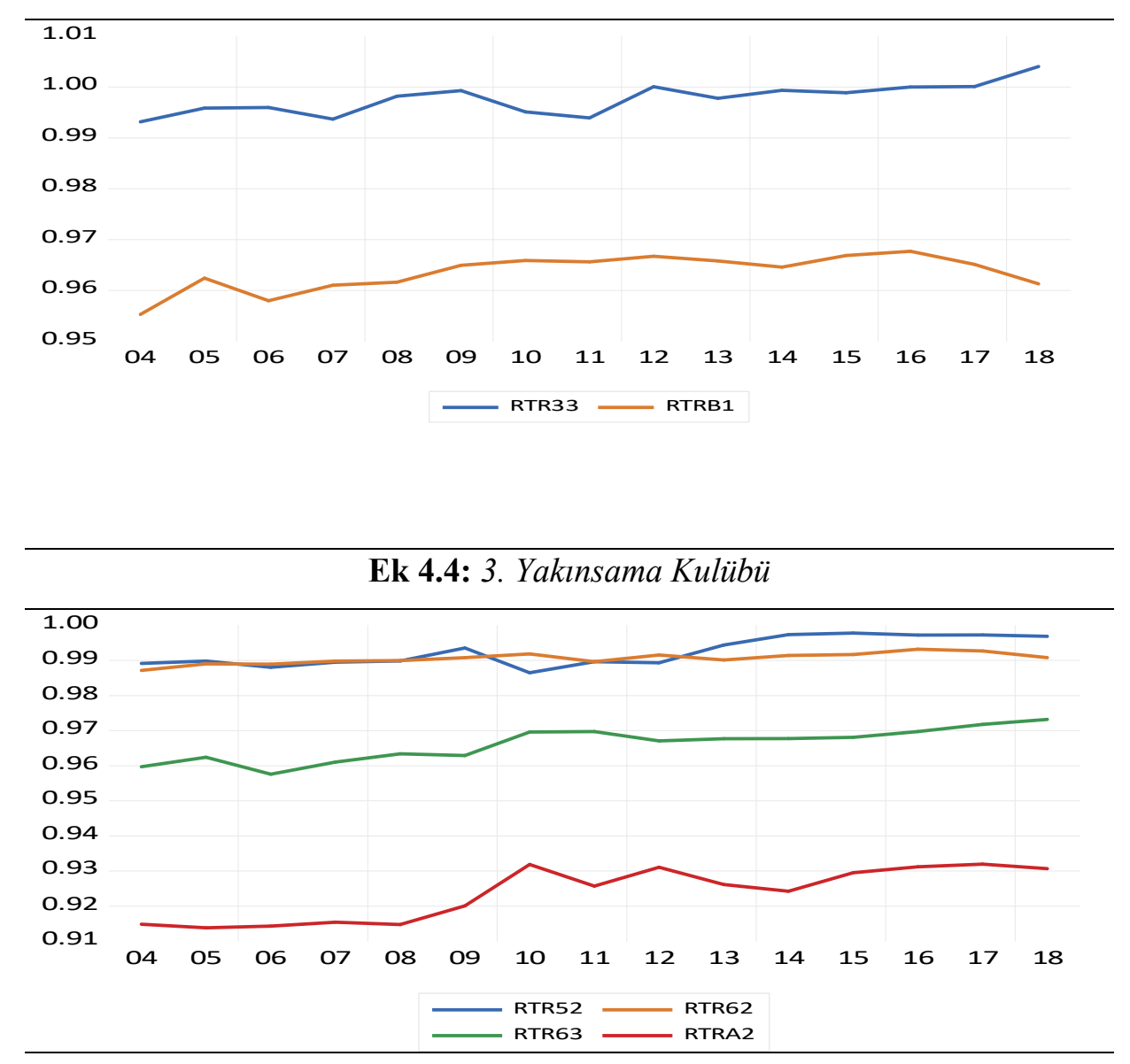
Türkiye'de Düzey-2 Bölgeleri Arasında Kişi Başı Gelir Yakınsama Kulüpleri Var Mıdır?
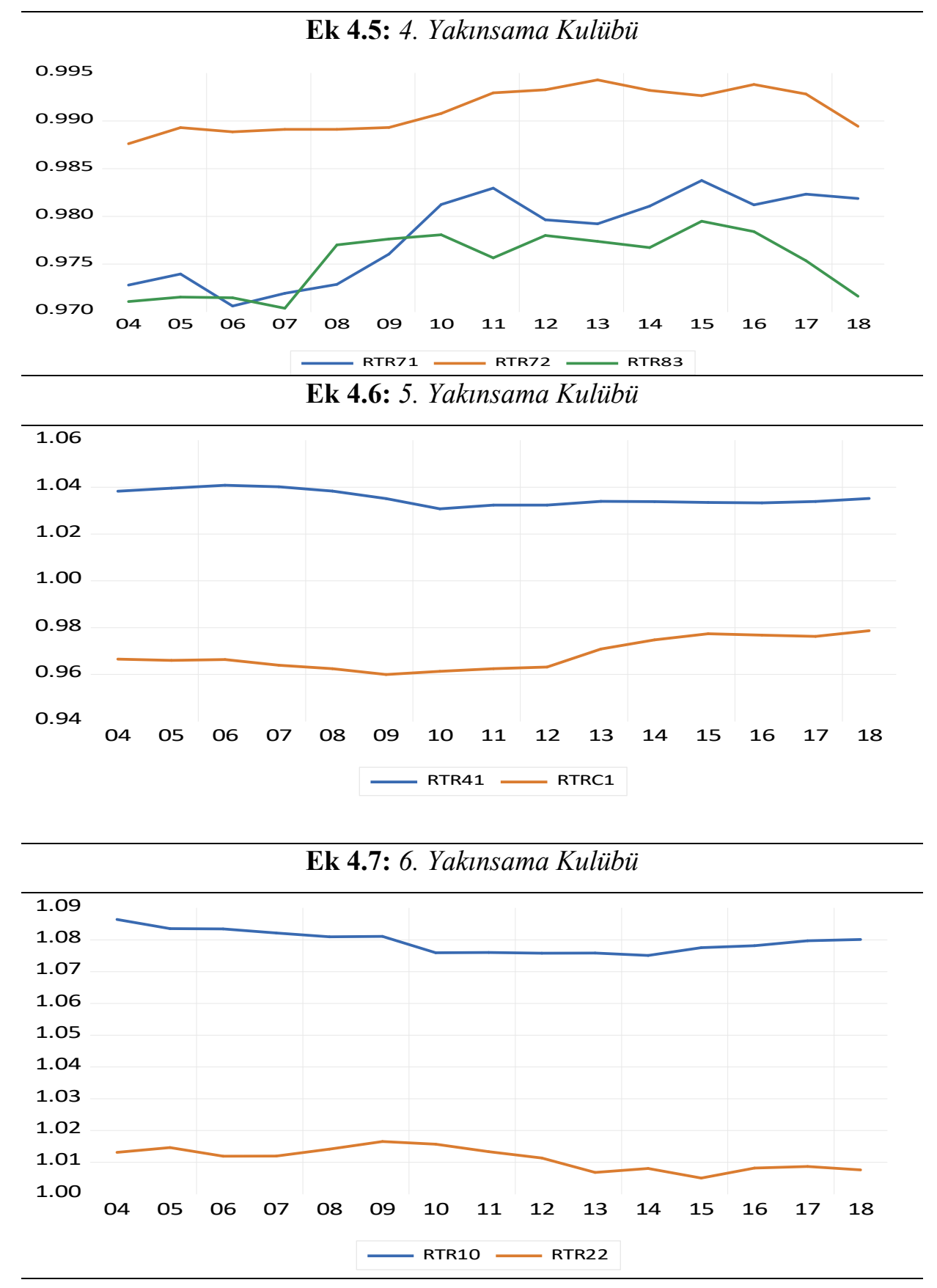


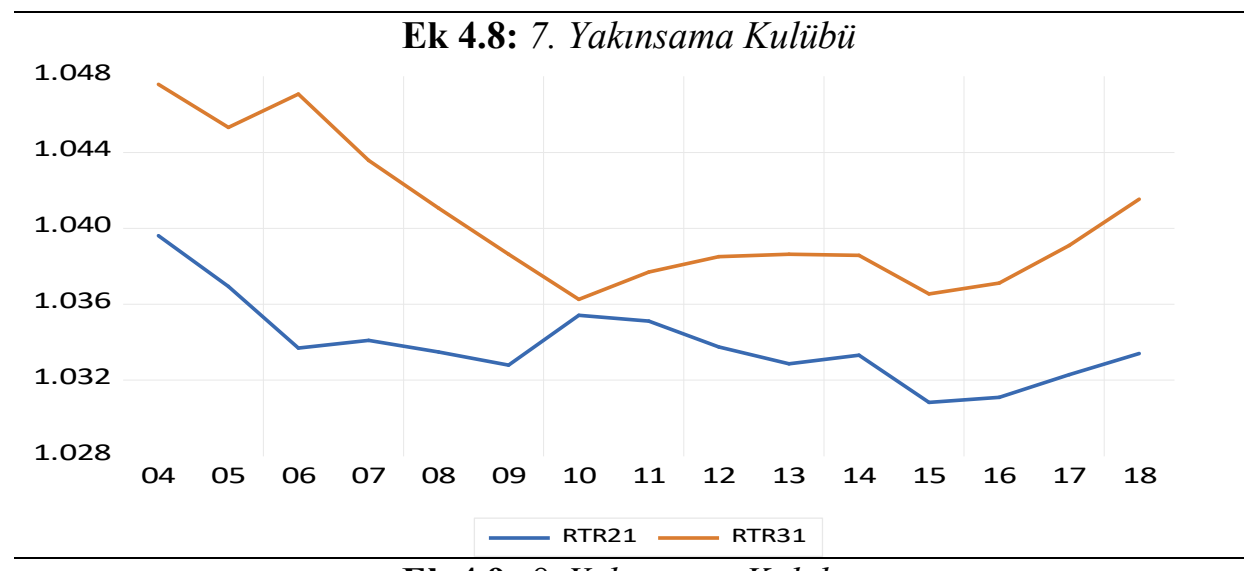

Ek 4.9: 8. Yakınsama Kulübü

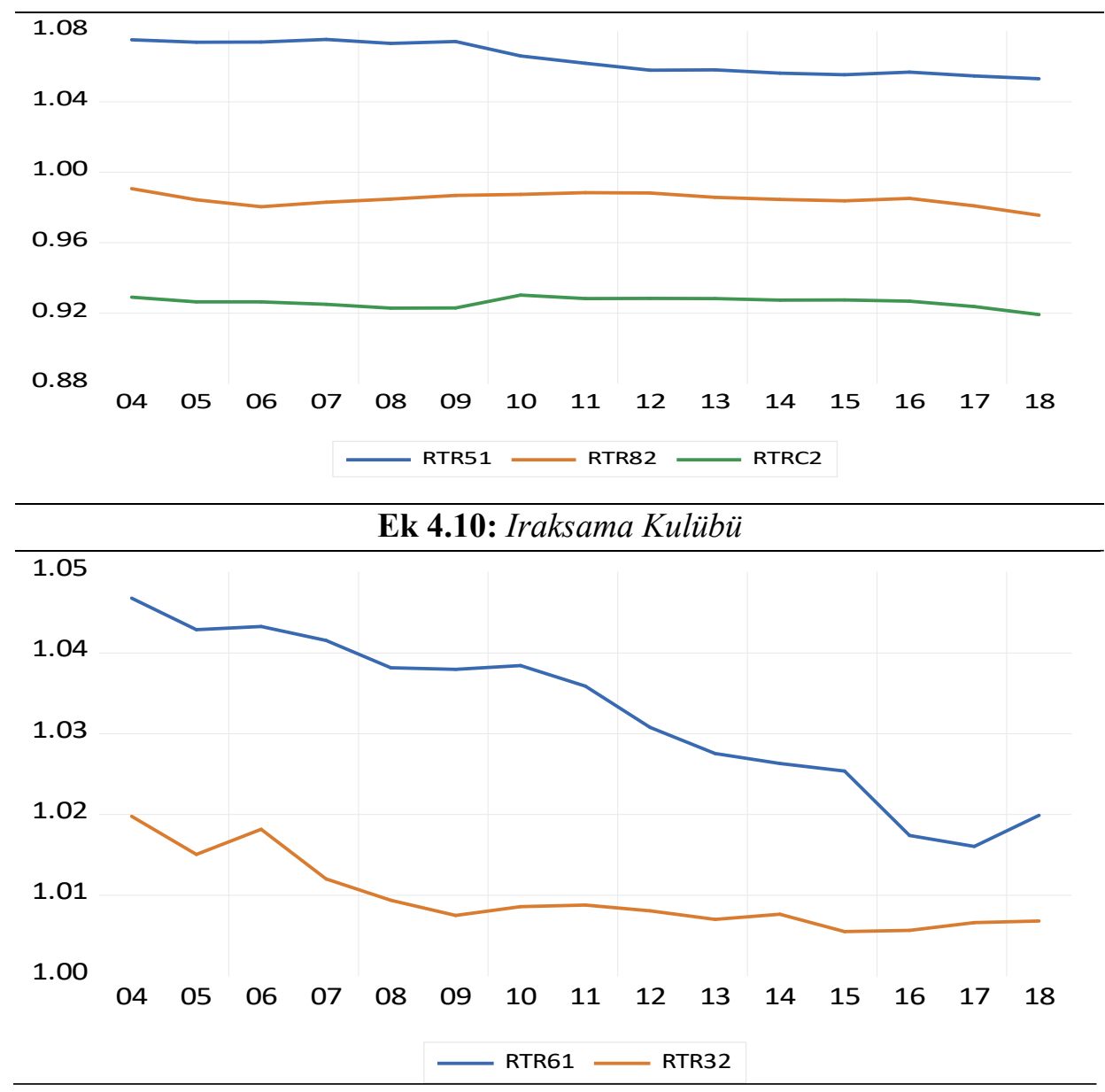

